\title{
REBUSAN RIMPANG ALANG-ALANG (IMPERATA CYLINDRICAL L) MEMBERIKAN EFEK DIURETIK PADA MENCIT (MUS MUSCULUS) DI MENIT KE 90
}

\author{
D. Elysa Putri Mambang \\ Jurusan Farmasi Poltekkes Kemenkes Medan
}

\begin{abstract}
Abstrak
Obat tradisional yang digunakan sebagai diuretik salah satunya adalah tumbuhan alang-alang (Imperata cylindrical $L$ ) dan yang digunakan adalah rimpangnya. Rimpang alang-alang mengandung manitol, glukosa, sakarosa, malic acid, citric acid, coixol, arundoin, cylindrene, cylindol A, graminone $\mathrm{B}$, imperanene, stigmasterol, campesterol, $\beta$-sitosterol, fernenol, arborinone, arborinol, isoarborinol, simiarenol, anemonin dan tanin. Penelitian ini bertujuan untuk menguji efek diuretik dari rebusan rimpang alang-alang yang diberikan secara oral pada mencit sebagai hewan percobaan. Rebusan pada penelitian ini adalah sediaaan cair yang dibuat secara merebus rimpang alang-alang dengan air pada suhu $90^{\circ} \mathrm{C}$ selama 30 menit. Penelitian ini merupakan penelitian eksperimental, dimana hewan uji yang digunakan adalah 18 ekor mencit, yang terbagi dalam 6 kelompok masing-masing kelompok terdiri dari 3 ekor mencit. Kelompok 1 sebagai kontrol (tidak diberikan apa-apa), kelompok 2 diberikan aquadest kelompok 3 diberikan rebusan rimpang alang-alang konsentrasi 30\%, kelompok 4 diberikan rebusan rimpang alang-alang konsentrasi 40\%, kelompok 5 diberikan rebusan rimpang alang-alang konsentrasi 30\% dan kelompok 6 diberikan suspensi furosemida. Mencit kelompok 1, 2, 3, 4, 5 dan 6 diteliti selama 4 jam. Hasil penelitian menunjukkan bahwa rebusan rimpang alang-alang konsentrasi 30\%, 40\% dan 50\% menghasilkan efek diuretik pada menit ke 90. Sedangkan suspensi furosemida memberikan efek diuretik pada menit ke 60. Suspensi furosemida lebih cepat memberikan efek diuretik dari pada rebusan rimpang alang-alang.
\end{abstract}

Kata Kunci : Rebusan rimpang alang-alang, Diuretik, Furosemida

\section{PENDAHULUAN}

Indonesia merupakan negara yang terkenal akan kekayaan sumber daya alamnya yang melimpah. Beraneka ragam tanaman dapat ditemukan di Indonesia. Hal tersebut didukung oleh iklim tropis dan posisi strategis Indonesia yang dilewati olah garis khatulistiwa. Kekayaan flora yang dimiliki tersebut kemudian banyak dimanfaatkan oleh masyarakat untuk kebutuhan hidup sehari-hari diantaranya sebagai tanaman obat.

Masyarakat Indonesia sejak dahulu kala telah melakukan serangkaian upaya penanggulangan penyakit menggunakan bahan-bahan dari alam sebagai pengobatan tradisional. Berdasarkan UU RI No. 36 Tahun 2009 tentang kesehatan, yang dimaksud dengan obat tradisional adalah bahan atau ramuan bahan yang berupa bahan tumbuhan, bahan hewan, bahan mineral, sediaan sarian (galenik), atau campuran dari bahan tersebut yang secara turun temurun telah digunakan untuk pengobatan, dan dapat diterapkan sesuai dengan norma yang berlaku di masyarakat.

Banyak orang beranggapan bahwa penggunaan dari obat tradisional relatif lebih aman dibandingkan dengan obat sintetis atau buatan pabrik. Penggunaan obat tradisional semakin meningkat diantaranya juga dikarenakan krisis ekonomi yang berpengaruh kepada daya beli masyarakat terhadap obat sintetis atau buatan pabrik. Namun demikian bukan berarti obat tradisional tidak memiliki efek samping yang merugikan. Untuk itu perlu diketahui kandungan dan penggunaan yang optimal dari obat tradisional tersebut.

Diantara berbagai tumbuhan obat yang diketahui baik bagi kesehatan yaitu rimpang alang-alang. Tanaman ini sudah lama dikenal masyarakat, banyak dijumpai di tempat terbuka. Akar dan batang alang-alang mengandung manitol, glukosa, sakarosa, malic acid, citric acid, coixol, arundoin, cylindrene, cylindol A, graminone $\mathrm{B}$, imperanene, stigmasterol, campesterol, $\beta$-sitosterol, fernenol, arborinone, arborinol, isoarborinol, simiarenol, anemonin dan tanin. (Dalimartha, 2006). Khasiat rimpang alang-alang antara lain diuretik, kencing berdarah, kencing nanah, muntah darah, mimisan dan radang ginjal akut. (Arief Hariana, 2004)

Akar alang-alang sudah pernah diteliti oleh Jaya Antonius Satrya, Fakultas Farmasi UNAIR untuk mengetahui efek antipiretik (pereda demam) infus akar 
alang-alang pada tikus putih. Hasil penelitian menunjukkan bahwa infus akar alang-alang konsentrasi 5\%, 10\%, dan 20\% mempunyai efek antipiretik. Infus akar alang-alang konsentrasi 20\% paling kuat efek antipiretiknya.

Furosemida digunakan untuk pengobatan diuretika, udema, kelainan ginjal (menghancurkan batu ginjal). Diuretika adalah zat-zat yang memperbanyak pengeluaran air kemih (diuresis) akibat khasiat langsung terhadap ginjal (Tjay Hoan, 2007). Istilah diuresis mempunyai dua pengertian, pertama menunjukkan adanya penambahan volume urin yang diproduksi dan yang kedua menunjukkan jumlah pengeluaran zat-zat terlarut dalam air (Ganiswara Sulistia G, 1995 ). Fungsi utama diuretik adalah untuk memobilisasi cairan udem, yang berarti mengubah keseimbangan cairan sedemikian rupa sehingga volume cairan ekstra sel kembali menjadi normal.

Berdasarkan uraian diatas, penulis tertarik untuk mengetahui dan membandingkan efek diuretik rebusan rimpang alang-alang (Imperata cylindrica L) dan furosemida terhadap volume urine mencit sebagai hewan percobaan.

\section{Tujuan Penelitian}

Penelitian ini bertujuan untuk mengetahui dan membandingkan efek diuretik rebusan rimpang alangalang (Imperata cylindrica L) dan furosemida terhadap volume urine mencit.

\section{Metode Penelitian}

Metode penelitian yang digunakan adalah metode eksperimental dengan membandingkan efek diuretik rebusan rimpang alang-alang dengan furosemida menggunakan mencit sebagai hewan percobaan

\section{Pengambilan Sampel}

Sampel yang akan diuji dalam penelitian adalah rimpang alang-alang segar yang didapat di daerah Pancing Medan. Tehnik pengambilan sampel adalah purposive sampling yaitu tidak mempertimbangkan tempat tumbuh dan letak geografisnya.

\section{Hewan Percobaan \\ Mencit 18 ekor}

\section{Alat dan Bahan yang Digunakan}

Alat yang digunakan dalam penelitian ini meliputi:Timbangan hewan (mencit), beaker glass $50 \mathrm{ml}$, $250 \mathrm{ml}$, oral needle, gelas ukur $10 \mathrm{ml}, 25 \mathrm{ml}, 250 \mathrm{ml}$, penampung urine (spuilt $3 \mathrm{ml}$ ), kandang, kandang metabolism,panci rebusan,stopwatch, kain flannel, lumpang dan stamper, corong .

Bahan yang digunakan: mencit, rebusan rimpang alang-alang, aquadest, $\mathrm{NaCl}$ 0,9\%,Suspensi furosemida.

\section{Pembuatan sediaan}

\section{Rebusan rimpang alang-alang}

Rebusan yang dibuat adalah rebusan dengan konsentrasi 30\%, 40\% dan 50\%
Perhitungan pembuatan rebusan rimpang alang-alang konsentrasi 30\% :

Rimpang alang-alang $30 \%=\frac{30}{100} \times 100 \mathrm{ml}=30 \mathrm{~g}$

Perhitungan pembuatan rebusan rimpang alang-alang konsentrasi $40 \%$ :

Rimpang alang-alang $40 \%=\frac{40}{100} \times 100 \mathrm{ml}=40 \mathrm{~g}$

Perhitungan pembuatan rebusan rimpang alang-alang konsentrasi 50\%:

Rimpang alang-alang 50\% $=\frac{50}{100} \times 100 \mathrm{ml}=50 \mathrm{~g}$

maka rebusan rimpang alang-alang dibuat dengan menimbang 30 g, 40 g dan 50 g rimpang alang-alang yang masih segar kemudian masing masing dimasukkan ke dalam panci rebusan dan diberi aquadest sebanyak $100 \mathrm{ml}$. Panaskan diatas penangas air selama 30 menit setelah suhu diatas $90^{\circ} \mathrm{C}$ sambil sesekali diaduk, kemudian serkai selagi panas dengan menggunakan kain flanel, jika volume kurang tambahkan air panas secukupnya melalui ampas hingga diperoleh volume $100 \mathrm{ml}$.

\section{Pembuatan pensuspensi CMC 0,5\%}

Sebanyak 0,5 g CMC ditaburkan kedalam lumpang yang telah berisi aquadest panas sebanyak $50 \mathrm{ml}$, dibiarkan selama 15 menit sehingga diperoleh massa yang transparan, setelah mengembang digerus lalu diencerkan dengan sedikit aquadest kemudian dimasukkan kedalam wadah. Cukupkan volume dengan aquadest hingga $100 \mathrm{ml}$

\section{Pembuatan Suspensi Furodemida 0,1\%}

Furosemida yang diambil adalah:

Furosemida $0,1 \%=\frac{0,05 \mathrm{~g}}{50 \mathrm{ml}} \times 50 \mathrm{ml}=0,05 \mathrm{~g}(50 \mathrm{mg})$

20 tablet furosemida $=2984 \mathrm{mg}$

Tiap tablet memiliki $40 \mathrm{mg}$ furosemida murni sehingga furosemida murni dalam 20 tablet adalah $800 \mathrm{mg}$

serbuk furosemida yang ditimbang adalah: $\frac{50}{800} \times 2984=$ $186,5 \mathrm{mg}$

\section{Perhitungan Volume Suspensi Furosemida}

Volume suspensi yang diberikan pada mencit:

- Berdasarkan tabel konversi dosis untuk mencit 20 g dibandingkan dengan manusia $70 \mathrm{~kg}=0,0026$

- Berdasarkan Farmakope Indonesia, dosis furosemid untuk manusia $=40 \mathrm{mg}$.

- Berat rata-rata orang Indonesia adalah $50 \mathrm{~kg}$

- Jadi untuk manusia yang beratnya $70 \mathrm{~kg}$ adalah = $\frac{70}{50} \times 40 \mathrm{mg}=56 \mathrm{mg}$

- Dosis Furosemida yang diberikan untuk mencit adalah $=56 \mathrm{mg} \times 0,0026=0,1456 \mathrm{mg}$

- Volume suspensi yang dibuat adalah $50 \mathrm{mg}$ dalam 50 $\mathrm{ml}$ 
- Volume suspensi furosemida yang dibutuhkan untuk mencit 20 g adalah:

$$
\frac{0,2 m g}{50 m g} \times 50 \mathrm{ml}=0,2 \mathrm{ml}
$$

Perhitungan Volume Rebusan rimpang alang-alang : $\frac{B B}{20 g}$ $\mathrm{x} 0,2 \mathrm{ml}$

Perhitungan Volume Aquadest : $\frac{B B}{20 g} \times 0,2 \mathrm{ml}$

Perhitungan Volume NaCl 0,9\%: $\frac{B B}{20 g} \times 0,2 \mathrm{ml}$

\section{Prosedur Kerja}

1. Mencit dipuasakan selama 12 jam

2. Mencit yang digunakan ditimbang, dicatat beratnya masing-masing dan diberi tanda.

3. Hitung volume rebusan rimpang alang-alang, dosis suspensi furosemida, aquadest dan volume $\mathrm{NaCl}$ $0,9 \%$

4. Semua mencit diberikan larutan $\mathrm{NaCl} 0,9 \% \mathrm{~b} / \mathrm{v}$ kecuali Mencit 1,2 dan 3 kemudian dibiarkan selama 15 menit

5. Mencit 1, 2, 3 tidak diberi apa-apa
6. Setelah 15 menit mencit 4, 5, 6 diberi aquadest

7. Setelah 15 menit mencit 7, 8, 9 diberi rebusan rimpang alang-alang konsentrasi 30\%

8. Setelah 15 menit mencit 10, 11, 12 diberi rebusan rimpang alang-alang konsentrasi $40 \%$

9. Setelah 15 menit mencit 13, 14, 15 diberi rebusan rimpang alang-alang konsentrasi 50\%

10. Setelah 15 menit mencit 16, 17, 18 diberi suspensi Furosemida

11. Setelah semua mencit diberikan obat kemudian dimasukkan kedalam kandang metabolisme

12. Amati dan catat perubahan

13. Catat volume urin tertampung setiap 30 menit selama 4 jam. Hitung efek diuretik dengan kriteria rumus:

$$
\frac{\mathrm{VUT}}{\mathrm{VOB}} \times 100 \%
$$

Dimana: VUT: Volume Urin Tertampung VOB: Volume Obat Diberikan

14. Tetapkan khasiat diuretik tiap mencit dengan kriteria: $\frac{\mathrm{VUT}}{\mathrm{VOB}} \times 100 \%=40 \%-80 \% \longrightarrow$ diuretik lemah $80 \%-100 \% \longrightarrow$ diuretik sedang $>100 \% \longrightarrow$ diuretik kuat

Dibuat grafik volume urine.

\section{Hasil Penelitian}

\begin{tabular}{|c|c|c|c|c|c|c|c|c|c|}
\hline \multicolumn{2}{|c|}{ Perlakuan } & \multicolumn{8}{|c|}{ Volume urin (ml) } \\
\hline & & $30 ’$ & $60^{\prime}$ & 90’ & 120’ & 150’ & 180’ & $210^{\prime}$ & $240^{\prime}$ \\
\hline Kontrol & Mencit 1 & 0 & 0 & 0 & 0 & 0 & 0 & 0 & 0 \\
\hline Kontrol & Mencit 2 & 0 & 0 & 0 & 0 & 0 & 0 & 0 & 0 \\
\hline Kontrol & Mencit 3 & 0 & 0 & 0 & 0 & 0 & 0 & 0 & 0 \\
\hline Aquadest & Mencit 4 & 0 & 0 & 0,1 & 0,1 & 0,1 & 0,1 & 0,1 & 0,1 \\
\hline Aquadest & Mencit 5 & 0,2 & 0,2 & 0,2 & 0,2 & 0,2 & 0,2 & 0,2 & 0,2 \\
\hline Aquadest & Mencit 6 & 0 & 0,1 & 0,1 & 0,1 & 0,1 & 0,1 & 0,1 & 0,1 \\
\hline RRA 30\% & Mencit 7 & 0 & 0 & 0,3 & 0,3 & 0,3 & 0,4 & 0,4 & 0,4 \\
\hline RRA 30\% & Mencit 8 & 0 & 0,1 & 0,1 & 0,2 & 0,2 & 0,2 & 0,3 & 0,3 \\
\hline RRA 30\% & Mencit 9 & 0 & 0 & 0,2 & 0,2 & 0,4 & 0,4 & 0,4 & 0,4 \\
\hline RRA $40 \%$ & Mencit 10 & 0 & 0,2 & 0,2 & 0,4 & 0,4 & 0,4 & 0,5 & 0,5 \\
\hline RRA $40 \%$ & Mencit 11 & 0,1 & 0,1 & 0,4 & 0,4 & 0,4 & 0,5 & 0,5 & 0,5 \\
\hline RRA 40\% & Mencit 12 & 0 & 0,2 & 0,2 & 0,3 & 0,4 & 0,4 & 0,6 & 0,6 \\
\hline RRA 50\% & Mencit 13 & 0 & 0,1 & 0,1 & 0,4 & 0,4 & 0,6 & 0,6 & 0,7 \\
\hline RRA 50\% & Mencit 14 & 0,2 & 0,2 & 0,6 & 0,6 & 0,7 & 0,7 & 0,8 & 0,8 \\
\hline RRA 50\% & Mencit 15 & 0,1 & 0,3 & 0,3 & 0,6 & 0,6 & 0,6 & 0,7 & 0,7 \\
\hline $\begin{array}{l}\text { Suspensi } \\
\text { furosemida }\end{array}$ & Mencit 16 & 0,3 & 0,3 & 0,7 & 0,7 & 0,9 & 1,0 & 1,0 & 1,0 \\
\hline $\begin{array}{l}\text { Suspensi } \\
\text { furosemida }\end{array}$ & Mencit 17 & 0 & 0,2 & 0,5 & 0,5 & 0,7 & 0,7 & 0,9 & 0,9 \\
\hline $\begin{array}{l}\text { Suspensi } \\
\text { furosemida }\end{array}$ & Mencit 18 & 0,1 & 0,3 & 0,3 & 0,3 & 0,7 & 0,7 & 0,7 & 0,9 \\
\hline
\end{tabular}

Tabel 1.1 Data pengamatan Volume Urin

Keterangan: RRA = Rebusan Rimpang Alang-alang 
Tabel 1.2 Rata-rata Volume Urin Tertampung Tiap 30 Menit Selama 4 Jam

Perlakuan rata-rata

Waktu (menit)

\begin{tabular}{|c|c|c|c|c|c|c|c|c|}
\hline & 30 & 60 & 90 & 120 & 150 & 180 & 210 & 240 \\
\hline Kontrol & 0 & 0 & 0 & 0 & 0 & 0 & 0 & 0 \\
\hline Aquadest & 0,06 & 0,1 & 0,13 & 0,13 & 0,13 & 0,13 & 0,13 & 0,13 \\
\hline RRA 30\% & 0 & 0,03 & 0,2 & 0,23 & 0,3 & 0,3 & 0,36 & 0,36 \\
\hline RRA 40\% & 0,03 & 0,16 & 0,26 & 0,36 & 0,4 & 0,43 & 0,53 & 0,53 \\
\hline RRA 50\% & 0,1 & 0,2 & 0,36 & 0,53 & 0,56 & 0,63 & 0,7 & 0,73 \\
\hline Suspensi Furosemida & 0,13 & 0,27 & 0,5 & 0,5 & 0,77 & 0,8 & 0,8 & 0,93 \\
\hline
\end{tabular}

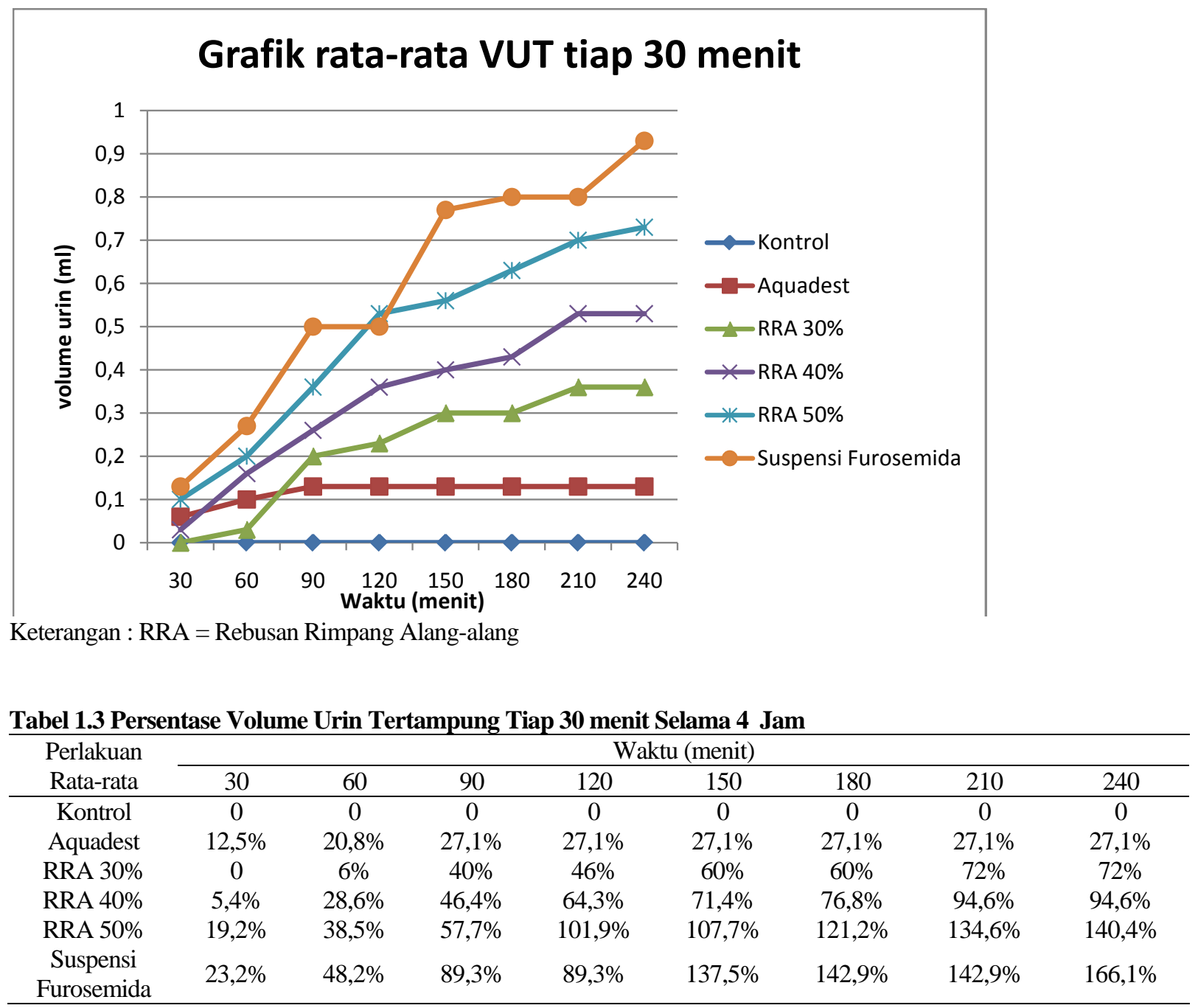




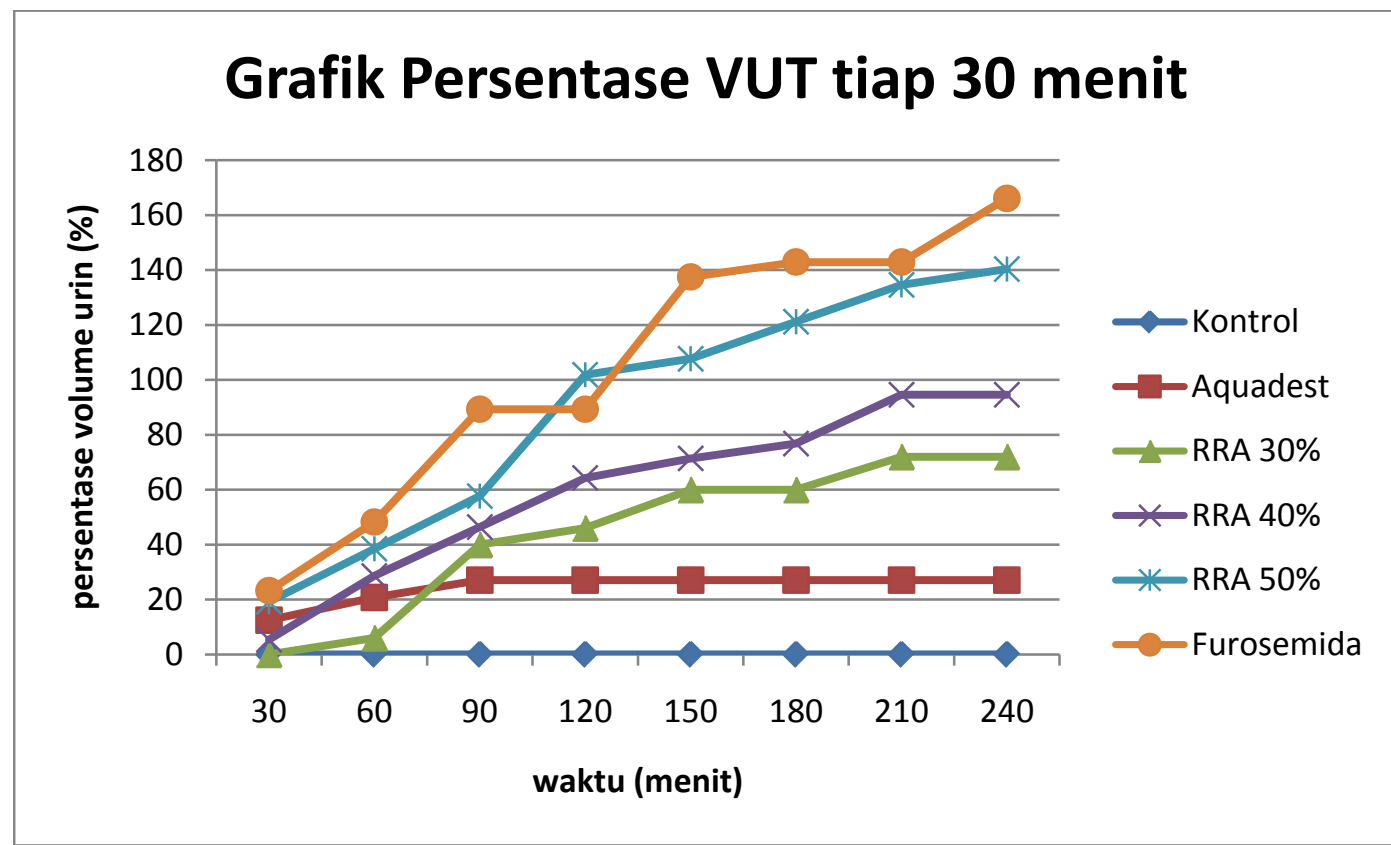

keterangan : persentase volume urin = VUT/VOB x 100\%

$$
\begin{gathered}
40 \%-80 \%=\text { diuretik lemah } \\
80 \%-100 \%=\text { diuretik sedang } \\
>100 \%=\text { diuretik kuat }
\end{gathered}
$$

Tabel 1.4 Nilai Kumulatif Volume Urin Tertampung Tiap Kelompok

\begin{tabular}{lc}
\hline Perlakuan & Rata-rata \% diuretik selama 4 jam \\
\hline Kontrol & 0 \\
Aquadest & $27,1 \%$ \\
RRA 30\% & $72 \%$ \\
RRA 40\% & $94,6 \%$ \\
RRA 50\% & $140,4 \%$ \\
Suspensi furosemida & $166,1 \%$ \\
\hline
\end{tabular}

\section{Persentase VUT selama 4 jam}

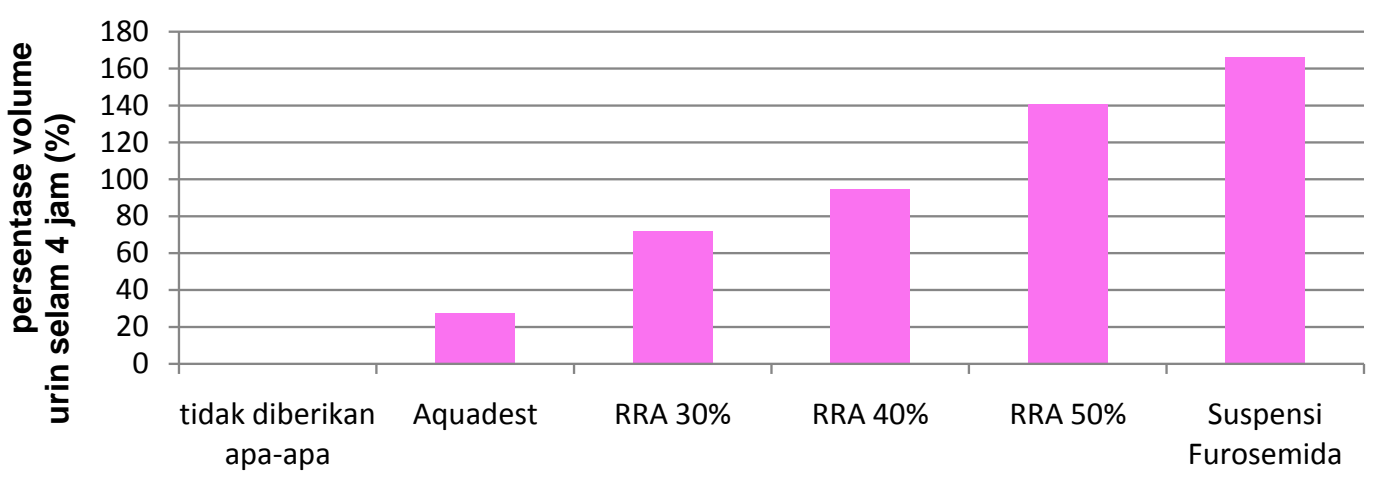

Sediaan yang diberikan

\section{Pembahasan}

Semua mencit kecuali mencit 1, 2 dan 3 diberi $\mathrm{NaCl}$ 0,9\% untuk menginduksi urin. Mencit yang diberi suspensi furosemida secara oral mengalami diuresis pada menit ke-30 dan mengeluarkan urin sebanyak 0,9 ml selama 4 jam pengamatan, suspensi furosemida dapat memberikan efek diuresis yang lebih cepat dibandingkan dengan rebusan rimpang alang-alang. Mencit yang diberikan rebusan rimpang alang-alang konsentrasi 30\% secara oral mengalami diuresis pada menit ke-60 dan mencit yang diberikan rebusan rimpang alang-alang konsentrasi 40\% dan 50\% mengalami diuresis pada menit ke-30.

Semua mencit yang diberikan rebusan rimpang alang-alang secara oral memberikan efek diuretik pada menit ke-90 dan volume urin yang 
dihasilkan selama 4 jam adalah mencit yang diberikan rimpang alang-alang 30\% sebanyak 0,36 ml, mencit yang diberikan rimpang alang-alang 40\% sebanyak $0,53 \mathrm{ml}$ dan yang diberi rebusan rimpang alang-alang $50 \%$ adalah $0,73 \mathrm{ml}$. Rebusan rimpang alang-alang 50\% memberikan efek diuretik kuat sedangkan rebusan rimpang alang-alang 40\% memberikan efek diuretik sedang dan rebusan rimpang alang-alang konsentrasi $30 \%$ memberikan efek diuretik lemah.

Suspensi furosemida lebih cepat memberikan efek diuretik dibandingkan rebusan rimpang alang-alang. Mencit yang diberikan aquadest tidak memberikan efek diuretik hal ini disebabkan aquadest tidak memiliki khasiat sebagai diuretic. Pada mencit 1, 2 dan 3 yang tidak diberikan apa-apa dan tidak mengeluarkan urin selama 4 jam pengamatan berlangsung.

\section{SIMPULAN DAN SARAN}

\section{Simpulan}

1. Rebusan rimpang alang-alang konsentrasi $30 \%, 40 \%$ dan 50\% memberikan efek diuretik

2. Mencit yang diberi rebusan rimpang alang-alang dengan konsentrasi 50\% lebih banyak mengeluarkan urin dibandingkan konsentrasi $40 \%$ dan 30\%, maka semakin tinggi konsentrasi rebusan rimpang alang-alang, semakin banyak urin yang dikeluarkan, semakin rendah konsentrasi rebusan rimpang alang-alang maka volume urin yang dikeluarkan semakin sedikit.

3. Rebusan rimpang alang-alang konsentrasi 30\%, 40\% dan 50\% menghasilkan efek diuretik pada menit ke 90. Sedangkan suspensi furosemida memberikan efek diuretik pada menit ke 60. Suspensi furosemida lebih cepat memberikan efek diuretik dari pada rebusan rimpang alang-alang.

\section{Saran}

Kepada peneliti selanjutnya disarankan dapat meneliti khasiat dari rimpang alang-alang dalam bentuk sediaan ekstrak.

\section{DAFTAR PUSTAKA}

Dalimartha, Setiawan.2006. Atlas Tumbuhan Obat Indonesia Edisi 4. Jakarta: Puspa Swara

Departemen Kesehatan Republik Indonesia. 1979. Farmakope Indonesia Edisi III. Jakarta

Jakarta

-----------, Farmakope Nederland Edisi V, Jakarta

Rahman, A. U., Chaudhary, M.i., William. J. R, 2005 Drug Development. Singapore: Hardwood Academic Publisher. Hal: 80

Ganiswara sulistia G, dkk, 1995, Farmakologi dan Terapi, edisi 4, Bagian Farmakologi, Fakultas kedokteranUniversitas Indonesia, Jakarta

Hariana, Arief, Drs. H., 2004, Tumbuhan Obat dan Khasiatnya seri 1, Jakarta: Penebar Swadaya

Tjay, Tan Hoan dan Kirana Rahardjo, 2007. Obat-Obat Penting Edisi Keenam. Jakarta: Gramedia

Voight, R.1994. Buku Pelajaran Teknologi Farmasi. Yogyakarta: Gadjah mada university press

Eko, Manfaat Tanaman alang-alang yang Baik untuk Kesehatan Tubuh. http://npicom.com/health/manfaat-tanaman-alangalang diakses tanggal 21 Februari 2013) 